\title{
Analysis of Local Government Debt Problems in Jilin Province
}

\author{
Gao Yuan ${ }^{1, a,{ }^{*}, \text { Zhou Huimin }}$,b, \\ ${ }^{1}$ Department of Accounting, School of Economics and Management, Changchun University of \\ Technology, Jilin, Changchun, China \\ ${ }^{2}$ Department of Accounting, School of Economics and Management, Changchun University of \\ Technology, Jilin, Changchun, China \\ a407222789@qq.com, b1620209598@qq.Com \\ ${ }^{*}$ Corresponding author
}

Keywords: Jilin Province; local government debt; problem; countermeasure

\begin{abstract}
In recent years, China's local government debt has grown rapidly, and the accumulating local government debt has become a difficult problem for governments. As society pays more attention to local government debt, it is too high. It has also aroused the concern of the central government and has become a potential problem affecting local economic development. Based on the actual situation, this paper carefully analyzes the current situation and potential dangers of local governments in Jilin Province, finds the problem, and formulates corresponding program strategies and puts forward targeted opinions and suggestions. The purpose is to effectively control the local government debt risk in Jilin Province and improve it. The utilization of funds to prevent the occurrence of local government debt.
\end{abstract}

\section{Introduction}

China's local government debt is divided into four levels: province, city, township, and four levels. Under the premise of imbalanced fiscal revenue and expenditure, the government's debt problems will lead to problems in daily operations, and to meet the needs of fulfilling various functions, through other Ways to get income. The government borrows through bank loans, issuing bonds, trust financing, borrowing from enterprises, and debt funds are mainly used for public infrastructure construction, promoting the economic development of the people's livelihood, and other government agencies have defined "local government debt". Mainly divided into direct debt, indirect debt and implicit debt.

\section{Status quo of local government debt development in Jilin Province}

In 2013, the balance of local government debt in Jilin Province was 258.093 billion yuan, an increase of 800 million yuan compared with 2012. At the end of 2017, the local government debt of Jilin Province was 319.327 billion yuan. In the past four years, local government debt grew at a faster rate. The government debt of Jilin Province mainly comes from bank loans. In 2013, the bank loan of Jilin Province was 138.706 billion yuan. The government debt of the spring city was 1662.36, the debt liability of Jilin Province was 38.335 billion yuan, and the debt of Tonghua Municipal Government was 131.15. The government debt is 9.947 billion yuan. According to the data released by the National Audit Office, the local government debt in Jilin Province has a controllable trend.

\section{Problems in local government debt in Jilin Province}

\subsection{Local government financial powers do not match}

The reform of the fiscal system was initiated by the Central Committee of China in 1994. The central government decided to divide the types of taxes into three categories: central tax, local tax, and central and local shared tax. Among them, the central tax is mainly the main tax type and the 
tax type with high income, and the place is divided into the opposite, the tax type is small, the income is low, and even the tax is difficult to collect. The central government will transfer its financial power to its own hands, but will delegate the power to the local government. The local tax revenue will decrease, which means that the local fiscal revenue will be reduced accordingly.

The decline in the financial resources of local governments is increasingly contradicted by the increasing expenditure on public expenditures and health care. The ratio of central government revenue to total fiscal revenue has risen from $15 \%-25 \%$ to $48 \%-55 \%$, and the scale of local fiscal expenditure. The proportion increased from $52.6 \%$ to $84.9 \%$. The local financial resources are lacking. The macroeconomics are driven by local economic growth. The characteristics of local government and financial power are not matched. The responsibility of local governments such as income cannot be In proportion, the local fiscal revenue ratio can only be maintained at less than $55 \%$, but the financial expenditure ratio is as high as $85 \%$. Under this contradiction, plus the central government's imperfect supervision of the localities, especially in the entire debt decision-making, it is separated from the supervision of the central government. Therefore, it will inevitably be financed in other ways, and the local government debt will expand without restriction.

\subsection{Local government debt growth in Jilin Province is fast}

After approval by the State Council in 2019, through the approval of the Ministry of Finance, Jilin Province included 31.7 billion debts approved in advance in 2019. The new local government debt limit was 65.2 billion yuan. At the end of 2018, the Ministry of Finance issued the province ahead of schedule. In 2019, the new debt limit was 31.7 billion yuan. According to the data approved by the Ministry of Finance, the scale of debts in Jilin Province has expanded rapidly in the past two years. The provincial debts are basically used for water conservancy construction, revitalization of villages, water supply, road construction, and construction of universities and other projects. Loan to all counties and cities in Jilin Province.

Since the country has been promoting the revitalization of the countryside and focusing on poverty alleviation, Jilin Province has always followed the leadership of the Party Central Committee and worked hard to fulfill the requirements of the Party Central Committee. Therefore, even if the economic development is getting better and better, the debt stock of Jilin Province has not been significantly reduced. Debt pressure has always existed. In addition, in order to meet the people's higher requirements for the quality of material life, the government actively invites investment to build more infrastructure, which will lead to further expansion of the government's debt. And because all local government debt data are reported by local governments themselves, the inevitable data will be flawed. In order to consider its own image and interests, the amount of real local government debt may be much larger than the data published by the statistics department. Therefore, the amount of debt of the Jilin Provincial Government is still very large.

The debt repayment pressure in Jilin Province has always existed. In order to meet the people's higher requirements for the quality of material life, the government actively invites investment to build more infrastructure, which will lead to further expansion of the government's debt.

\subsection{Lack of local government management functions}

Another important factor in the increase of local government debt risk in Jilin Province is the lack of local government debt management functions in Jilin Province. The establishment of the mechanism for the supervision and resolution of local government debt in Jilin Province has not reached a sound and perfect level. For this reason, the Jilin provincial government has encountered great difficulties in managing debt.

As of 2019, the online financial report of Jilin Province that can be found can only be found in 2014. This audit report is also the only audit report that can be found. For the local government debt data of the Jilin Provincial Government, it is difficult to find the specific data updated after 2014. The introduction of government documents such as relevant laws and regulations is also concentrated in the documents of Jilin Province in the past three years. The official website of the government is rarely seen. This shows that the Jilin provincial government does not pay much attention to debt, or put more emphasis on the economic development of Jilin Province. 


\section{Suggestions for the response of local government debt risk in Jilin Province}

\subsection{Strengthening the evasion of the scale control of local government debt risk in Jilin Province}

The borrowing behavior of local government debt is an economic act of borrowing with government credit as a guarantee. If the local government fails to repay the arrears, the government credit as a guarantee for debt will go bankrupt, and once the government credit goes bankrupt, it will damage the economic development. Therefore, in order to prevent problems from occurring, effective control of local government debt risks is a top priority.

Due to the vast territory of Jilin Province, there are many administrative agencies under the provincial capital, and the cities and counties are different in different regions. The economic environment and economic development are also different, resulting in the fiscal revenue and financial expenditure of each county and city. The scale of borrowing is also different, so Jilin Province can not establish a fixed and unified standard of local government debt. It can be seen that Jilin Province wants to effectively control the scale of local government debt at all levels of counties and cities, and the degree of scale control must be matched with the fiscal revenue and expenditure of each county and city, which can better promote the economic development of each region. It is necessary to find and establish a management and control mechanism for the optimal scale of local government debt in Jilin Province.

\subsection{Improve the emergency response system for local government debt in Jilin Province}

The local government debt emergency response system in Jilin Province is actually that when the early warning indicators of local government debt reach the warning line, the Jilin provincial government should respond in a timely manner and take effective measures to minimize the losses caused by debt risks. If you want to make proper treatment as soon as possible at the time of debt risk, it will take a long time to accumulate. The provincial government should conduct long-term monitoring and evaluation of debt risks. For various types, the structure is different and the characteristics are not exhaustive. The same debt risk is well known. After doing this, when the debt risk occurs, the government will identify the debt risk in time, and then through this emergency response system, the debt risk will be resolved step by step, preventing the situation from further worsening and leading to worse outcomes. In order to improve the debt risk emergency response system, it is necessary to set up a special response agency to find a dedicated staff to collect data analysis data, as well as professional staff who can quickly respond to local government debt risks. It is necessary to merge the department with the provincial government's department for managing local government debt in a large department, which can monitor and manage the local government debt of Jilin Province, collect and collect data on local debt, and analyze Including any relevant data information such as fiscal revenue and expenditure, select appropriate methods to evaluate the risk of local government debt, and make appropriate emergency response in case of emergency.

\subsection{Improve the debt repayment reserve system of Jilin Province}

The Jilin Provincial Government plans the debt budget every year. The budget should fully consider the financial income of the Jilin Provincial Government, and have a clear understanding of the economic status of the county and city governments, so as to understand the provinces and provinces at all levels in Jilin Province. The government has made a debt repayment plan for its own economic situation, and proposed a debt repayment reserve that suits its own financial situation. However, this plan is separately listed in the government's annual government budget. However, the Jilin Provincial Government has not accurately explained the source of the debt repayment funds. We can discuss the following aspects of the debt repayment funds:

Jilin Province's tax revenue and tax revenue are an important part of Jilin Province's fiscal revenue. In 2018, tax revenue accounted for $75 \%$ of the total fiscal revenue. The number of tax revenues completed in the Jilin Province tax budget plan this year is counted, and then the statistics are collected this year. The remaining debt amount is drawn from the tax income by one-third of the remaining amount of the debt. 
The operating income of projects completed with local government debt funds, the relevant departments shall count the total amount of projects completed in the construction of government debt funds in Jilin Province. From the day when the operating income begins to be generated, the debt repayment reserve can be proportionally Extracted from the total income of each item. Administrative income, in addition to taxes in Jilin Province's fiscal revenue, also includes administrative income, and the source of funds for the debt repayment reserve can be drawn from the proportion. The special fund-raising fund, Jilin Province will arrange the financial budget by the financial department at the beginning of each year. There will be a special account in the budget to prepare the debt-servicing reserve.

From the above-mentioned several fiscal revenues including the fiscal reserves, the compensation reserve should be owned by the Jilin Provincial Department of Finance, which is responsible for local government debt, and should be classified into a special account for unified management, and should be regularly upgraded to the higher level. The department and the Jilin Provincial People's Congress report to them, accept their supervision of the use of funds, and regularly seek the audit department to audit the account, prevent the irregular use of the debt reserve, or be secretly possessed by private individuals, affecting local government. The repayment of debt increases the provincial debt risk of Jilin.

\section{Conclusion}

Local government debt is closely related to social and economic development, social stability, and residents' living standards. The government's reasonable borrowing of funds is conducive to stabilizing employment, social stability promotes local economic development, balances fiscal expenditures, and alleviates local fiscal pressure. On the contrary, it is too high. Government debt will bring government debt risks, trigger a crisis of government trust, and cause social unrest. Therefore, in order to promote the sound and rapid development of Jilin Province's economy, solving the local government debt problem in Jilin Province has become a top priority.

\section{Acknowledgment}

This paper is a phrased research achievement on the Social Science and Technology Project of Jilin Provincial Science and Technology Department named "A study on the risk response of Local Government debt in Jilin Province", contrast number 20190601059FG.

\section{References}

[1] Feng Liyang. Analysis of the problems and countermeasures of local government implicit debt management [j]. China's collective economy, 2019, (9): 49-50.

[2] Kong Yanyan. Measurement and prevention of local government debt risk under the background of new urbanization--Taking Jilin Province as an example [d]. Jilin: Changchun University of Technology Master's thesis, 2018.

[3] Li Jiayi. Research on local government debt problems in Jilin Province [d]. Jilin: Master's thesis of Northeast Normal University, 2016.

[4] Zheng Yang. Research on local government debet risk management in Jilin City [d]. Jilin: Master's thesis of Jilin University of Finance and Economics, 2018. 